Although preliminary, the results suggest that L.A.I. in microtest plates is comparable to L.A.I. in glass tubes. The plates are easier to use and require less extract. Counting non-adherent cells by Coulter counter is faster and possibly more objective than microscopic examination. Our observation that with breast carcinoma extracts L.A.I. was positive in 3 of 7 patients with fibrocystic disease and 14 of 16 patients (88\%) with confirmed breast cancer but none of 20 patients with other gynæcological malignancies may indicate cross-reactivity between benign and neoplastic breast-tissue antigens. ${ }^{3}$ One tumour patient reacted to extracts from her own tumour and several other breast carcinomas suggesting cross-reactivity between tumours of the same histological type. Further work with purified extracts is needed to establish the validity of the L.A.I. phenomenon for tumour-specific diagnosis.

We thank Miss G. Fedra for technical assistance. This work is supported by grant from the Deutsche Forschungsgemeinschaft (SFB 136, Heidelberg).

Medizinusche Universitätsklinik,

D. FRITZE

D-69 Heidelberg, Germany

C. SChulte-Uentrop

M. KAUFMANN

\section{HEMOCHROMATOSIS AND SUPEROXIDE METABOLISM: FREE-RADICAL INFLUENCED IRON STORAGE?}

SIR,- - The letter from Dr Moldow and Dr Bloomfield (July 15, p. 154) focuses on a possible role for stored iron in potentiating superoxide-ion-induced tissue damage. I suggest that alteracions in superoxide ion $\left(\mathrm{O}_{2}^{-}\right)$metabolism may contribute to the genetic ætiology of "idiopathic" hæmochromatosis.

Studies on iron transfer between proteins in vitro show that the ferrous state is required; ${ }^{4} 5$ dietary studies have demonstrated that deficiency of ascorbic acid, ${ }^{6}$ usually considered a reducing agent, ${ }^{7}$ accelerates iron accumulation. It seems likely that a decreased capacity for intracellular movement of iron between the many proteins involved in its metabolism would lead to increased ferritin accumulation followed by lysosomal degradation to hæmosiderin. ${ }^{8}$ Drugs such as streptonigrin, daunomycin, doxorubicin, and porphyromycin are predicted to increase $\mathrm{O}_{2}^{-}$levels ${ }^{9}$ and could hinder iron reduction.

The association if idiopathic hæmochromatosis with the A3 and B14 HLA antigens ${ }^{10}$ and the linkage of the disease to the HLA locus even in the absence of these antigens ${ }^{11}$ could possibly be related to altered metabolism of $\mathrm{O}_{2}^{-}$. The structural locus for mitochondrial superoxide dismutase, the enzyme which is responsible for inactivation of $\mathrm{O}_{2}^{-}$, is located on chromosome 6 with HLA. ${ }^{12}$ A mutant with decreased levels of superoxide dismutase could be in linkage disequilibrium with HLA (although the map distance seems too great unless there is cross-over suppression) and lead to hæmochromatosis. In mice, where the major histocompatability locus (H2) shares almost all the known features of the HLA locus, a locus controlling a catalase-modifying enzyme is closely linked to $\mathrm{H} 2 .^{13}$ Since catalase functions to remove the hydrogen peroxide produced by superoxide dismutase, altered catalase activities could also affect iron reduction. The hypothesis of an HLAlinked locus affecting $\mathrm{O}_{2}^{-}$metabolism and, thus, hæmochromatosis can be tested by studying these enzymes and HLA

4. Mazur, A., Baez, S., Shorr, E. F. biol. Chem. 1955, 213, 147.

5. Miller, J. P. G., Perkins, D. J. Eur. F. Biochem. 1969, 10, 146.

6. Lipschitz, D. A., Bothwell, T. H., Seffel, H. C., Wapnick, A. A., Charlton, R.W.Br. F. Hamat. 1971, 20, 155.

7. Dormandy, T. L. Lancet, $1978, \mathrm{i}, 647$.

8. Trump, B. F., Valigorsky, J. M., Arstila, A. U., Mergner, W. J., Kınney, T. D., Am.F. Path. 1973, 72, 295.

9. McCord, J. M., Fridovich, I. Ann. intern. Med. 1978, 89, 122.

10. Simon, M., Bourel, M., Fauchet, R., Genetet, B., Gut, 1976, 17, 332.

11. Simon, M., Bourel, M., Genetet, B., Fauchet, R. New Engl. F. Med. 1977, 297, 1017.

12. McKusick, V. A., Ruddle, F. H. Science, 1977, 196, 390

13. Hoffman, H. A., Grieshaber, C. K., Brochem. Genet. 1976, 14, 59. antigens in an accessible tissue (perhaps lymphocytes or fibroblasts) from individuals in families segregating for hæmochromatosis. The possible role of xanthine oxidase, an $\mathrm{O}_{2}^{-}$producing enzyme, in the mobilisation of iron ${ }^{14}$ needs to be clarified.

There are alternative hypotheses to explain the HLA-association of hæmochromatosis. Since HLA antigenic glycoproteins are major components of the plasma membrane, they may have effects on membrane transport of iron. The catalasemodifying enzyme in mice may be the same as one which modifies the lysosomal enzyme- $\alpha$-mannosidase. ${ }^{15}$ If an analogous locus exists in man, altered lysosomal metabolism of iron-containing compounds is a possibility.

Department of Human Genetics,

Medical School,

University of Michigan,

Ann Arbor, Michıgan 48109, U.S.A.

ROBERT P. ERICKSON

\section{BENEFICIAL EFFECT OF D.D.A.Y.P. ON} BLEEDING-TIME IN VON WILLEBRAND'S DISEASE

SIR,-A major advance in the management of hæmophilia and von Willebrand's disease has been the introduction of 1-deamino-8-D-arginine vasopressin ${ }^{1}$ (D.D.A.V.P.) which enables surgery to be done without the attendant hazards and expense of blood-product transfusion. A rise in factor-vin-related antigen (vIII Ag), von Willebrand's factor, and factor viII coagulant activity after intravenous D.D.A.v.P. infusion has been recorded. ${ }^{12}$ We have recently observed shortening of the bleeding-time (as measured by the template method) on repeated occasions in two young women who were having dental extraction. The results are summarised in the table. The time interval between the doses of D.D.A.v.P. (given in $30 \mathrm{ml}$ of saline over a $10 \mathrm{~min}$ period) was $12 \mathrm{~h}$ and the effect on bleeding-time lasted less than $12 \mathrm{~h}$ and was less apparent on the second occasion.

EFFECT OF D.D.A.V.P.

\begin{tabular}{|c|c|c|c|c|c|c|c|}
\hline \multirow{2}{*}{ Patient } & \multicolumn{2}{|c|}{$\begin{array}{l}\text { Bleeding-time } \\
\quad(\mathrm{min})\end{array}$} & \multicolumn{2}{|c|}{$\begin{array}{l}\text { virI coagulant } \\
\text { actuvity }(\%)\end{array}$} & \multicolumn{2}{|c|}{ vIII $\mathrm{Ag}(\%)$} & \multirow{2}{*}{$\frac{\text { D.D.A.V.P. } \mu \mathrm{g} / \mathrm{kg}}{0.6}$} \\
\hline & $\begin{array}{c}\text { Pre } \\
5\end{array}$ & $\begin{array}{l}\text { Post }^{*} \\
3 \cdot 5\end{array}$ & $\begin{array}{l}\text { Pre } \\
20\end{array}$ & $\begin{array}{l}\text { Post* }^{*} \\
>100\end{array}$ & $\begin{array}{c}\text { Pre } \\
0\end{array}$ & $\begin{array}{c}\text { Post } \\
54\end{array}$ & \\
\hline & 15 & 7 & 28 & $>100$ & $<12 \cdot 5$ & 88 & 0.5 \\
\hline & 15 & 9 & 24 & 68 & 50 & 86 & 0.5 \\
\hline
\end{tabular}

* "Post" levels taken $1 \mathrm{~h}$ after infusion.

The quality of the clot formed and the rate of healing of the sockets both appeared entirely normal in contrast to the slower healing usually experienced in similar patients treated with cryoprecipitate, antifibrinolytic agents, and antibiotics, as noted in a previous paper on D.D.A.V.P. treatment. ${ }^{1}$ There were no problems with fluid retention or increase in blood-pressure in our patients, the only side-effect being severe burning pain along the course of the vein during the third of the three injections given to one of the women.

In von Willebrand's disease, giving blood products raises factor-vIII coagulant activity but often does not correct the bleeding-time. Blood-product replacement during surgery is often monitored by the factor-vin coagulant activity. ${ }^{1-4}$

14. Green, S., Mazur, A. 7. biol. Chem. 1958, 227, 653

15. Dizik, M., Elliott, R. W. Blochem. Genet. 1978, 16, 247

1. Manucci, P. M., Ruggerı, Z. M., Pareti, F. I., Capitaniu, A. Lancet, 1977, 1,869 .

2. Manucci, P. M., Pareti, F. I., Holmberg, B., Nilsson, I. M., Ruggerı, Z. M., 7. Lab. clin. Med. 1976, 88, 662 .

3. Btggs, R., Matthews, J. M., Br f. Hamat. 1963, 9, 203.

4. Nilsson, I. M., Magnusson, S., Borchgrevink, C. Thromb. Diath. heemorrh. $1963,10,223$. 